\title{
Effects of Biodegradable Insecticides on Biofilter Bacteria: Implications for Aquaponics
}

\author{
Božidar Rašković ${ }^{1, *} \mathbb{B}$, Petr Dvořák², Jan Mráz²
}

\begin{abstract}
${ }^{1}$ University of Belgrade, Faculty of Agriculture, Institute of Animal Science, Nemanjina 6, Zemun, 11080 Belgrade, Serbia.

2University of South Bohemia in České Budějovice, Faculty of Fisheries and Protection of Waters, South Bohemian Research Center of Aquaculture and Biodiversity of Hydrocenoses, Institute of Aquaculture and Protection of Waters, Na Sádkách 1780, 37005 České Budějovice, Czech Republic.
\end{abstract}

\section{How to cite}

Rašković, B., Dvořák, P., Mráz, J. (2021). Effects of biodegradable insecticides on biofilter bacteria: implications for aquaponics. Turkish Journal of Fisheries and Aquatic Sciences, 21, 169-177. http://doi.org/10.4194/1303-2712-v21_4_02

\section{Article History}

Received 10 August 2020

Accepted 07 January 2021

First Online 14 January 2021

Corresponding Author

Tel.: +381114413289

E-mail: raskovic@agrif.bg.ac.rs

\section{Keywords}

Nitrification

Azadirachtin

Chlorpyrifos

Pyrethrin

\begin{abstract}
Even though aquaponics is the production system that is increasingly gaining focus, there is an absence of publications studying the use of pesticides in the aquaponics. Therefore, the aim of this study was to assess negative effects of one synthetic (chlorpyrifos) and two botanical insecticides (azadirachtin and pyrethrin) to matured biofilter in plastic buckets. The effectiveness of biofilter bacteria is determined indirectly, as concentrations of ammonia, nitrites and nitrates in the water were measured at $0 \mathrm{~h}, 5 \mathrm{~h}, 13 \mathrm{~h}, 21 \mathrm{~h}, 29 \mathrm{~h}, 37 \mathrm{~h}, 45 \mathrm{~h}$ and $53 \mathrm{~h}$ after insecticides application. The results showed negative effects of azadirachtin on the first step of nitrification, as concentration of ammonia was higher comparing to other groups for almost every sample point. Negative effects on second step of nitrification and higher concentrations of nitrites in the water were also detected, but no statistical differences were observed in the present study, due to the large variation between buckets. Nitrates were lower in water treated with azadirachtin from 29 hours from start to the end of the experiment. Application of other two insecticides to biofilter did not cause any effects and showed no difference comparing to the control group
\end{abstract}

\section{Introduction}

Aquaculture is the fastest growing food production sector during the last 40 years (Troell et al., 2014). With an average annual rate of $7.8 \%$ in the period $1990-2010$, it exceeded all other sectors of livestock production (Troell et al., 2014). Today, fish produced in aquaculture account for more than a half of total consumed fish worldwide (Blanchard et al., 2017). To achieve sustainability of aquaculture production during this period of remarkable growth, integrated culture systems gained focus, and one of the most popular integrated systems is aquaponics (Turcios \& Papenbrock, 2014).

Aquaponics represents combination of recirculating aquaculture system (RAS) and cultivating plants in the water (hydroponics). The general idea of integrating these two systems began during 1970s (Junge et al., 2017), and since then, aquaponics production is steadily growing and used not only in family farms, but also at commercial scales. It serves as primary source of income for around 30\% farmers who own aquaponics in the United States (Love et al., 2015), and is also getting more popular in Europe (Villarroel et al., 2016). There is now an emerging possibility of transforming food production in developing countries, especially ones having subtropic or tropic climate (König et al., 2016).

Aquaponics is often advertized as eco-friendly production and there are several recommendations for non-chemical methods and the use of integrated pest management in aquaponics (Goddek et al., 2015; 
Sirakov et al., 2016). On the other hand, after long-term use of the same aquaponics system, the presence of pests and diseases is increasing and the use of pesticides could be considered (Bittsánszky et al., 2015). Pesticides are very effective against insects, bacterial, fungal and viral diseases that could affect plants, but due to their chemical structure, they can be toxic to fish and other aquatic organisms. Some groups of pesticides, like pyrethroids, are extremely toxic to fish, with mean lethal concentrations ( $\mathrm{LC}_{50}$ ) below $10 \mu \mathrm{g} \mathrm{L}^{-1}$ (Bradbury \& Coats, 1989). Another issue is that synthetic pesticides are more persistent comparing to botanical and can remain in the aquaponics for a long time. This represents a significant problem in consumption of fish from aquaponics, since most of synthetic insecticides are lipophylic, easily soluble in biological membranes, penetrating fish organism and later stored in lipid or muscle tissue. Available alternative to synthetic insecticides are botanical insecticides, extracted from plants, acting as neurotoxins toward insects, with main feature being that they are easily biodegradable in water and when exposed to sunlight. Examples of these types of insecticides are: azadirachtin, extracted from neem (Azadirachta indica) seeds and several types of pyrethrin compounds, extracted from chrysanthemum (Chrysanthemum cinerariifolium) plant. These insecticides are widely and routinely used as plant production products in traditional crop science, as well as in hydroponics (Ujváry, 2010), and this was rationale for their use in the present study. Pyrethrum and azadirachtin are believed to be most widely used botanical insecticides globally, but accurate usage per state or continent cannot be found in the FAO statistics or in scientific publications (Isman, 2020). It also has to be stressed that pyrethrum is used more frequently comparing to its synthesized chemical analog, pyrethrin, used in the present study.

Apart from fish, pesticides could also have a negative impact on biofilter bacteria in aquaponics setup (Goddek et al., 2015). Biofilter is necessary element in every aquaponics system, receiving effluents from fish tank, while bacteria populating filter are essential for nitrifying process in the water. Tank effluents in aquaculture contain dissolved nutrients, mainly nitrogen and phosphorus, various inorganic and organic compounds, and suspended solids. These components originate from uneaten feed and metabolic wastes from the fish. The main metabolic product of fish is ammonia, a toxic molecule which induces several negative effects on the same fish that excrete it (Eddy \& Williams, 1987). In the first place, high environmental ammonia impairs ammonia excretion of fish or even causes a net uptake of ammonia from the water, which leads to deleterious effects in fish (Randall \& Tsui, 2002). The process of converting toxic ammonia to nitrates could be completed in one or two step process, depending on microorganism inhabiting biofilter. In two step process, first step is converting ammonia to nitrite by ammoniaoxidizing bacteria (AOB; e.g. Nitrosomonas sp.) and archaea (AOA; e.g. Thaumarchaeota sp.), while the second step is converting nitrite to nitrate by nitriteoxidizing bacteria (NOB; e.g. Nitrobacter sp.). This twostep process can also be completed by a single microorganism (e.g. Nitrospira sp.) in complete ammonia oxidation (comammox), as recently discovered (van Kessel et al., 2015). Similar to ammonia, nitrite is also toxic to fish, but to lesser extent (Wuertz et al., 2013). The described processes results in constant reduction of ammonia levels in water and less toxic effects on fish (Effendi et al., 2017). Bacteria in biofilters are usually from two distinctive groups: autotrophic nitrifiers (responsible for oxidising ammonia to nitrate), and heterotrophs (degrade organic matter using available oxygen in the water) (Blancheton et al., 2013). It is also known that pesticides application have stimulating (increase of growth), negative (decrease of growth) or neutral effect on soil nitrifying microorganisms (Ahmed et al., 1998; Lo, 2010), but no research up to date was conducted for biofilters which could be used in the aquaponics.

The aim of the study was to apply synthetic and botanical insecticides to water containing working biofilter and to test biofilter efficiency in amelioration of ammonia stress by measuring concentrations of ammonia, nitrites and nitrates in the water.

\section{Materials and Methods}

Prior to the beginning of the study, a large biofilter was assembled at Faculty of Fisheries and Protection of Waters, University of South Bohemia in Ceske Budejovice (Czech Republic). Biofilter consisted of a polyethylene tank with a $400 \mathrm{~L}$ volume, containing $250 \mathrm{~L}$ of dechlorinated tap water and $50 \mathrm{~L}$ of already matured $12 \times 10 \mathrm{~mm}$ BT10 carrier elements - plastic beads (Ratz Aqua and Polymer Technik, Germany) with surface area of $790 \mathrm{~m}^{2} \mathrm{~m}^{-3}$. To ensure proper population of carrier elements with biofilter bacteria, the effectiveness of biofilter was monitored 30 days prior to the beginning of the experiment. During this period, ammonium chloride (Penta, Czech Republic) was added daily to the water, with the aim to achieve approximate level of 3 $\mathrm{mg} \mathrm{L}^{-1}$ of ammonia and simulate the presence of ammonia excreted by fish, while also some fish feed is added to enrich the water with the organic matter. At the same time, $\mathrm{pH}$ of the water was adjusted daily to maintain values above 7 , with an addition of sodium bicarbonate, in order to prevent water acidification, which will slow down or stop nitrification process. Effectiveness of the biofilter was proved, by being able to reduce ammonia concentrations in the water from 3 to $0 \mathrm{mg} \mathrm{L}^{-1}$ in $24 \mathrm{~h}$ time, and nitrites in concentration of $1 \mathrm{mg} \mathrm{L}^{-1}$ in $24 \mathrm{~h}$ time. However, this reduction is not the sole effect of biofilter bacteria, as in alkaline water, ammonium ion have tendency to leave the aquatic environment. Twelve polyethylene buckets of total volume $50 \mathrm{~L}$ were used in the trial in order to mimic water environment in the RAS system. Each bucket was 
filled with $15 \mathrm{~L}$ of water from the tank containing $2.5 \mathrm{~L}$ of carrier elements also picked up from the same tank. Buckets were well aerated using air stones and kept indoor, without temperature control of the water. Daily addition of ammonium chloride continued, while small amount of fish feed (Biomar Iberia, Spain) was added to each bucket in order to introduce more organic substrate for the bacteria. After period of 7 days, in which we were assured that biofilter bacteria were effective in all buckets by daily measuring of basic water parameters and nitrogen compounds (details are given below), $33 \%$ of the water was changed, due to the high levels of nitrates, and application of pesticides started. Three different types of commercially available insecticides (water-soluble formulations) were applied to water in the buckets in triplicates: Group PYR - active substance: pyrethrin; product: ND Spruzit AF (W Neudorff, Germany); Group AZA - active substance: azadirachtin; product: Neem Azal - T/S (Biocont Laboratory, Czech Republic); Group CHL - active substance: chlorpyrifos; product: Reldan 22 (Dow AgroSciences, USA); Group CON - control (no insecticide was added to the water).

First two insecticides are of botanical origin and biodegradable due to photolysis and should leave aquatic environment in 50 hours, while third one is organophosphorus synthetic insecticide, with also solid biodegradable properties. Prior to addition to the buckets, insecticides were dissolved in small amount of distilled water using vortex mixer. The amount of insecticides applied was determined from the label intended for their use and based on the simulation of aquaponics system (Somerville et al., 2014): water volume of $15 \mathrm{~L}$ was intended for nutrient film technique aquaponics system with approximately $1 \mathrm{~m}^{2}$ of surface covered with plants. Of total pesticides applied to the 1 $\mathrm{m}^{2}$, we estimated that around $10 \%$ would end up in the water, with combination of dissipation and phloem transport. Therefore, the amounts of commercial products applied were: $0.1 \mathrm{~mL}$ of PYR, $0.3 \mathrm{~mL}$ of AZA and $0.01 \mathrm{~mL}$ of $\mathrm{CHL}$, which corresponded to following nominal concentrations of insecticides in the water: $7 \mu \mathrm{g}$ $\mathrm{L}^{-1}$ (PYR), $20 \mu \mathrm{g} \mathrm{L^{-1 }}$ (AZA) and $0.7 \mu \mathrm{g} \mathrm{L}^{-1}$ (CHL). During the next 53 hours (time frame in which botanical insecticides should degrade in the water), following time points were chosen for the assessment of nitrogen compounds in the water: Oh (beginning of the experiment), 5h, $13 \mathrm{~h}, 21 \mathrm{~h}, 29 \mathrm{~h}, 37 \mathrm{~h}, 45 \mathrm{~h}$ and $53 \mathrm{~h}$. At each time point, water samples $(50 \mathrm{~mL})$ were taken from each bucket and immediately processed in the laboratory. Concentrations of: ionized ammonianitrogen $\left(\mathrm{NH}_{4}{ }^{+}-\mathrm{N}\right)$, nitrite $\left(\mathrm{NO}_{2}^{-}\right)$and nitrate-nitrogen $\left(\mathrm{NO3}^{-} \mathrm{N}\right)$ were determined by reagent colorimetric method and measured at 412 and 540 and $410 \mathrm{~nm}$, respectively (APHA 1992). All measurements are performed using Spectroquant Pharo 100, (Merck KGaA, Germany). Later, total ammonia nitrogen (TAN) concentrations were calculated using table values (Svobodová et al., 1993), while nitrite-nitrogen values were obtained by multiplying nitrite concentrations with 0.304. Before each sampling, basic parameters of water quality were measured: temperature, $\mathrm{pH}$, concentration of dissolved oxygen HI98194 (Hanna Instruments, Romania) and electroconductivity using multiparameter probe WA-100ATC (Voltcraft, Taiwan). Ammonium chloride was added to the buckets at $0,16^{\text {th }}, 32^{\text {nd }}$ and $48^{\text {th }}$ hour from the start of the trial, in order to obtain concentrations of $3 \mathrm{mg} \mathrm{L}^{-1}$ in each bucket. All obtained data were tested for normality and homoscedasticity using Shapiro-Wilk's and Levene's test, respectively. After passing both tests, data were compared between groups using one-way ANOVA with post-hoc Tukey's HSD test.

\section{Results}

Basic water quality parameters during the trial are given in Table 1 and as highlighted, there were no significant difference between groups $(P>0.05)$.

Concentrations of ammonia in the buckets during the trial showed regular changes: increasing levels when ammonium chloride is added and subsequently decreasing with mean concentrations ranging from $<0.01$ to $0.54 \mathrm{mg} \mathrm{L}^{-1}$ after 13 hours (Fig 1). At the beginning of the trial $(0 \mathrm{~h})$, there was no statistical difference between groups, but after $5 \mathrm{~h}$ of conducting the trial, mean values of ammonia in AZA group were higher comparing to control $(P=0.04)$. In almost every subsequent sampling (excluding only the one at $29 \mathrm{~h}$ ), mean values of ammonia from AZA group were significantly higher comparing to all other groups $(P<0.05)$. At sampling point 13,29 and $45 \mathrm{~h}$ in AZA group, levels of ammonia varied from 0.07 to $0.54 \mathrm{mg} \mathrm{L}^{-1}$, while concentrations in other sampling points were in the range from $<0.01$ to $0.09 \mathrm{mg} \mathrm{L}^{-1}$.

Nitrite concentrations at the beginning of the trial were low in all groups, ranging from 0.13 to $0.17 \mathrm{mg} \mathrm{L}^{-1}$, and increasing during the first $21 \mathrm{~h}$ of the trial (Fig 2).

Table 1. Basic physico-chemical parameters (mean values \pm standard deviations) of water during the trial.

\begin{tabular}{lllll}
\hline \multirow{2}{*}{ Parameter } & Group & & & \\
\cline { 2 - 5 } & PYR & AZA & CHL & \multicolumn{2}{c}{ CON } \\
\hline Temperature $\left({ }^{\circ} \mathrm{C}\right)$ & $20.1 \pm 0.1$ & $20.2 \pm 0.1$ & $20.1 \pm 0.1$ & $20.1 \pm 0.1$ \\
$\mathrm{pH}$ & $7.51 \pm 0.14$ & $7.46 \pm 0.16$ & $7.51 \pm 0.13$ & $7.52 \pm 0.18$ \\
Dissolved oxygen $\left(\mathrm{mg} \mathrm{L}^{-1}\right)$ & $9.38 \pm 0.17$ & $9.45 \pm 0.13$ & $9.48 \pm 0.15$ & $9.44 \pm 0.13$ \\
Electroconductivity $\left(\mu \mathrm{Sm}^{-1}\right)$ & $559 \pm 73$ & $541 \pm 81$ & $560 \pm 74$ & 0.827 \\
\hline
\end{tabular}

No significant differences between groups was noticed (one-way ANOVA followed by Tukey's HSD post-hoc test, P $>0.05$ ) 


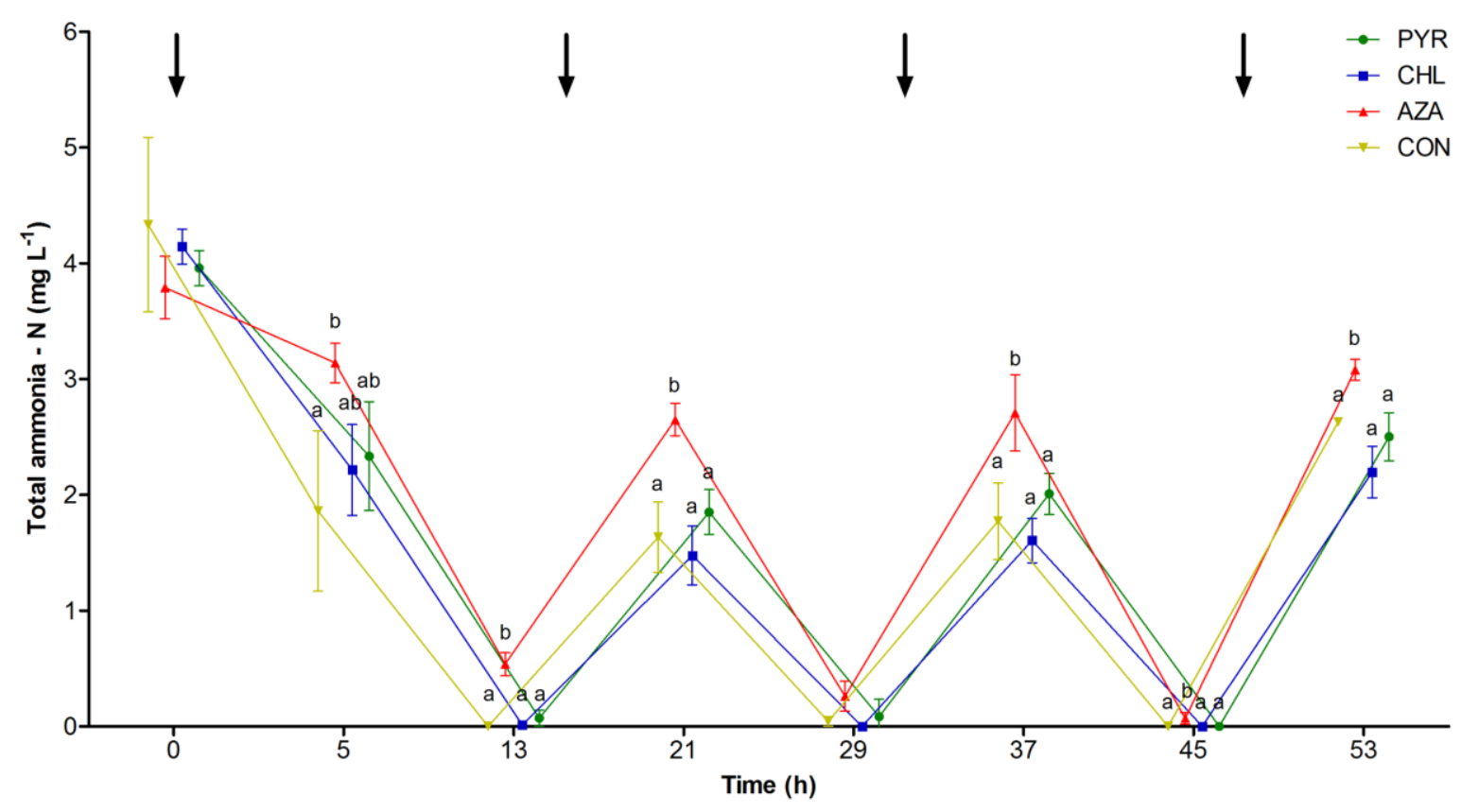

Figure 1. Concentrations (mean values \pm standard deviations) of total ammonia - nitrogen during the course of the trial. Lines with different colors and symbols represent pesticide which is added to the experimental buckets at the beginning of the trial (PYR pyrethrin; CHL - chlorpyrifos; AZA - azadirachtin; CON - control (no pesticide)); Mean values of sampling points are slightly shifted to the left or to the right in order to distinguish difference between groups; arrows indicate time of addition of ammonium chloride to the buckets; different lower case letters represent significant differences between groups within the same sampling point (oneway ANOVA followed by Tukey's HSD posthoc test, $\mathrm{P}<0.05$ )

After this sampling point, groups CON, PYR and CHL exhibited rhythm similar to the one already described for ammonia, although peak-to-bottom amplitudes were lower comparing to ammonia concentrations. On the other hand, nitrite concentrations of AZA group did not show the mentioned rhythm, instead constantly increasing and peaking at $3.07 \mathrm{mg} \mathrm{L}^{-1}$ after $53 \mathrm{~h}$. Statistical significance was recorded at the first sampling point $(0 \mathrm{~h})$, when mean nitrite concentrations in AZA group were lower comparing to other groups $(P<0.05)$ and at the second point $(5 \mathrm{~h})$ when mean nitrite concentrations in AZA group were lower comparing to the control $(P<0.05)$. There were no differences in later time points due to the high variation among buckets.

Contrary to specific increase-decrease trend present in the concentrations of ammonia and nitrites (for three groups), concentrations of nitrate are generally increasing during the course of the trial (Fig 3). At the start of the trial, mean concentrations of nitrates were in the range from 88.3 to $103.5 \mathrm{mg} \mathrm{L}^{-1}$, while at the sampling points of $5 \mathrm{~h}$ and $29 \mathrm{~h}$, mean concentrations of AZA group were significantly lower comparing to CON group $(P<0.05)$. At the last three sampling points $(37 \mathrm{~h}$, $45 \mathrm{~h}$ and $53 \mathrm{~h}$ ) mean concentrations of AZA group was significantly lower comparing to mean concentrations of all three groups $(P<0.01)$.

Shortly after the beginning of the experiment, in all three buckets from the AZA group, foam started to develop on the surface of the water. The foam remained during the course of the experiment, while it was not present in any of the other buckets.

\section{Discussion}

The present study was designed as a very possible scenario in the aquaponics production as we complied with all the instructions for application of insecticides at plants, and assuming $10 \%$ from the total application as dissipation and phloem transport. To authors' knowledge, there are no published studies concerning the amount of insecticides ending up in the aquaponics RAS system after application, and little available data in hydroponics. In one published study 7 various synthetic pesticides (organochlorins and pyrethroids) were applied to hydroponics cultivation of Gerbera flowers (Gerbera jamesonii) in the greenhouse (Hatzilazarou et al., 2004). 24 hours after application, concentrations in the water drain in hydroponics system ranged from 0.5 to $18 \mu \mathrm{g} \mathrm{L}^{-1}$ (Hatzilazarou et al., 2004), which is in line with nominal concentration applied to water in the present study. Moreover, concentrations applied in the present study were below $96 \mathrm{~h} \mathrm{LC}_{50}$ for several fish species found in the literature (Table 2).

As shown in Table 2, $96 \mathrm{~h} \mathrm{LC}_{50}$ concentrations are varying considerably. Those variations are depending on a number of factors, such as: exposed species, insecticide formulation, fish age, size, body mass and environmental conditions. In any case, concentrations of insecticides used in the present study were not supposed to cause mortality to any of the fish species reared in aquaponics system, not even to fish from Salmonidae family, which are frequently highlighted as more sensitive to pesticides comparing to other 


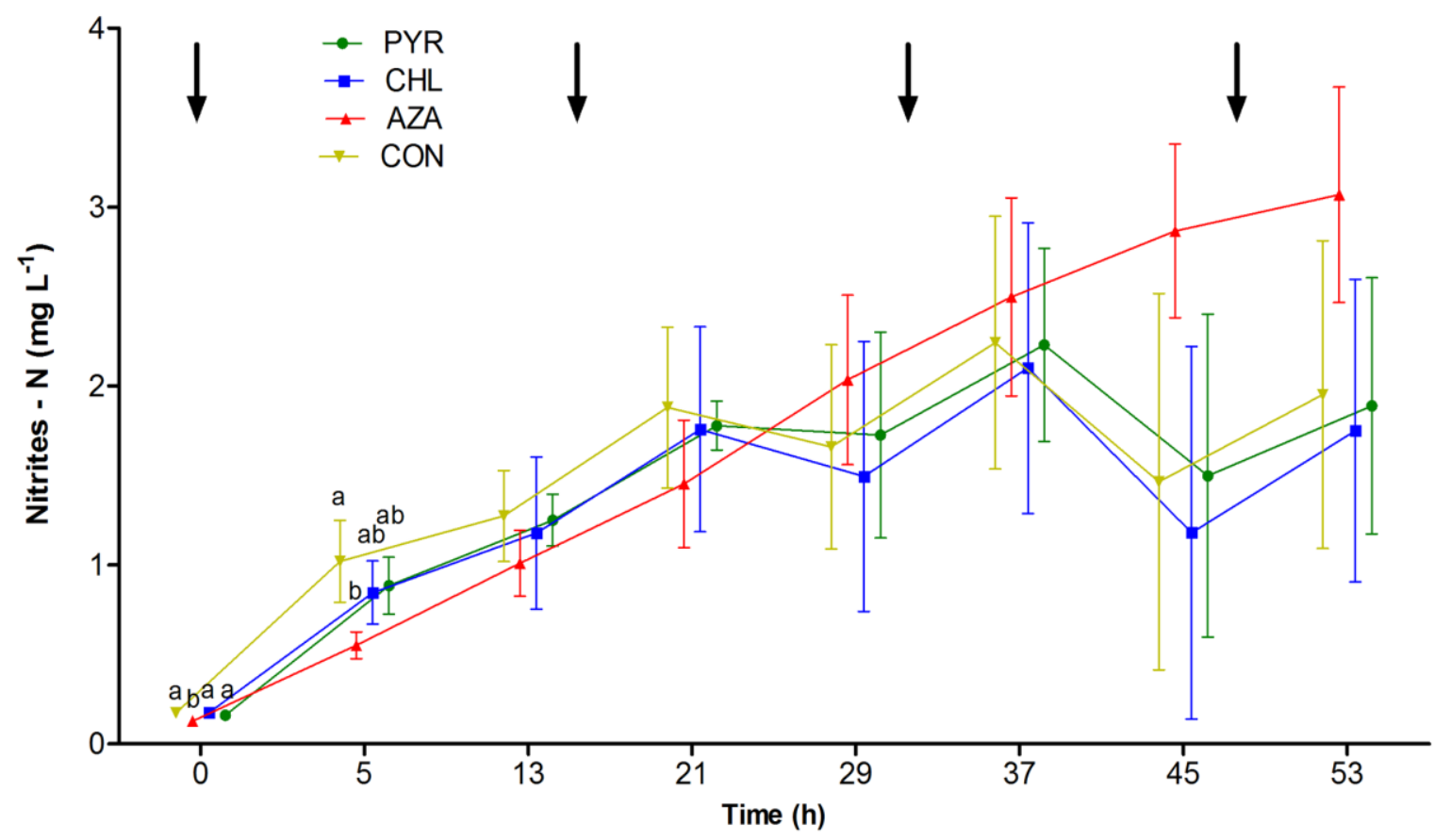

Figure 2. Concentrations (mean values \pm standard deviations) of nitrites - nitrogen during the course of the trial. Lines with different colors and symbols represent pesticide which is added to the experimental buckets at the beginning of the trial (PYR pyrethrin; CHL - chlorpyrifos; AZA - azadirachtin; CON - control (no pesticide)); Mean values of sampling points are slightly shifted to the left or to the right in order to distinguish difference between groups; arrows indicate time of addition of ammonium chloride to the buckets; different lower case letters represent significant differences between groups within the same sampling point (oneway ANOVA followed by Tukey's HSD posthoc test, $\mathrm{P}<0.05$ )

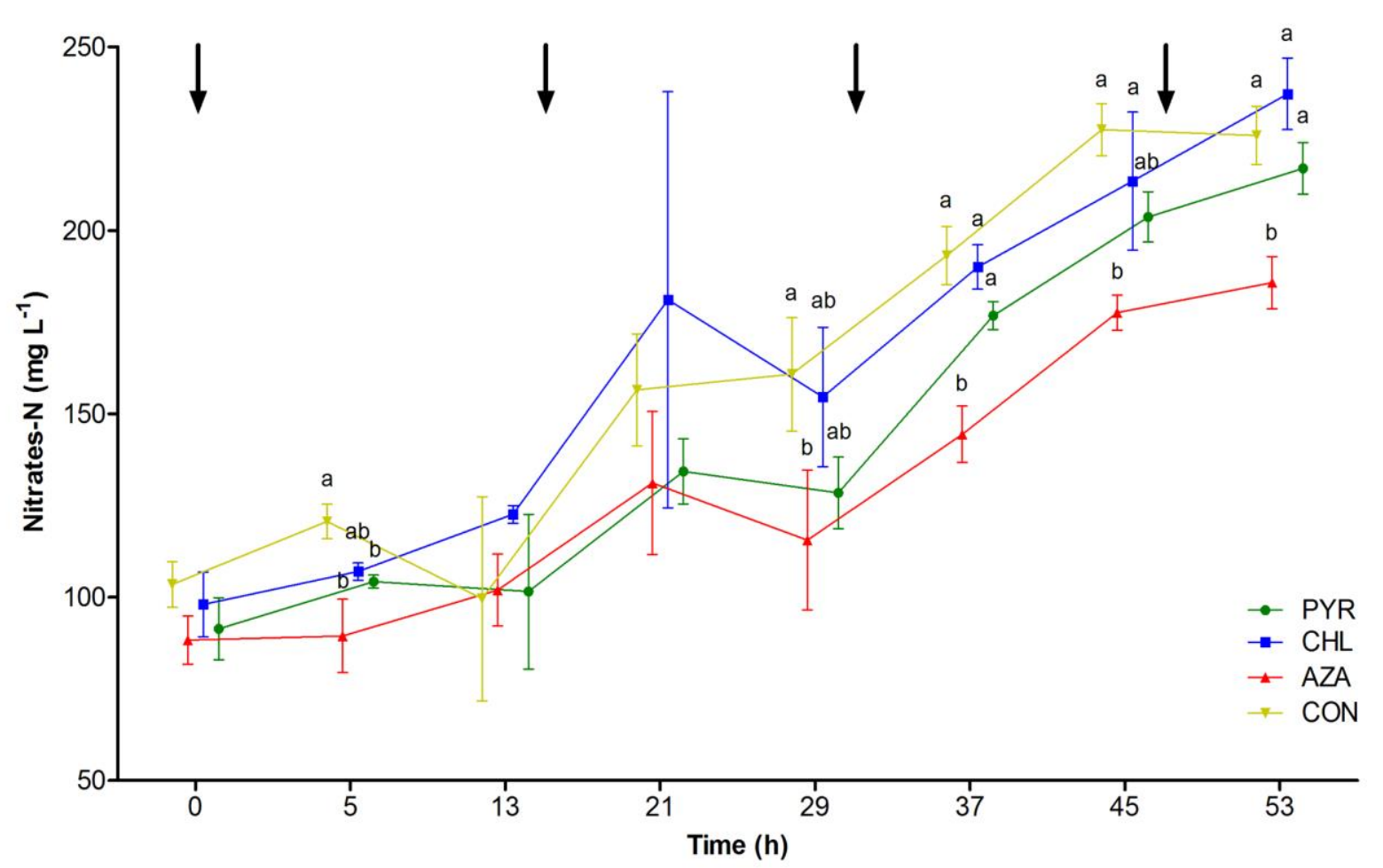

Figure 3. Concentrations (mean values \pm standard deviations) of nitrates - nitrogen during the course of the trial. Lines with different colors and symbols represent pesticide which is added to the experimental buckets at the beginning of the trial (PYR pyrethrin; CHL - chlorpyrifos; AZA - azadirachtin; CON - control (no pesticide)); Mean values of sampling points are slightly shifted to the left or to the right in order to distinguish difference between groups; arrows indicate time of addition of ammonium chloride to the buckets; different lower case letters represent significant differences between groups within the same sampling point (oneway ANOVA followed by Tukey's HSD posthoc test, $\mathrm{P}<0.05$ ) 
freshwater fish families (Macek \& McAllister, 1970).

From the start of the experiment, ammonia concentrations in the water were reduced to very low values in 13 hours, confirming efficiency of first step of nitrification in biofilters. The same was not true for the second step of nitrification, which took $21 \mathrm{~h}$ for obtaining characteristic rhythm and therefore, efficiency. Lower concentrations of nitrite- $\mathrm{N}$ were found after $5 \mathrm{~h}$, which could be explained by lower concentrations at the beginning and lower efficiency of $A O B / A O A$ in AZA group. This lag in the efficiency of NOB is quite common in newly-established RAS systems (Krüner \& Rosenthal, 1983), and could also be explained by the partial change of the water prior to the beginning of the experiment. The concentrations of $\mathrm{NO}_{2}-\mathrm{N}$ were not significantly higher comparing to other groups, due to the large variability between groups, but rising trend of $\mathrm{NO}_{2}-\mathrm{N}$ in AZA group is pointing to high impact on second step of nitrification in the aquaponics. Reason for intra-group variability and growing difference in standard deviation over time is probably due to the change of bacterial communities. On the other hand, it is now known that two previously mentioned pivotal bacterial species (Nitrosomonas spp., as $\mathrm{AOB}$ and Nitrobacter spp., as NOB) are usually in very low quantities in biofilters, and that $\mathrm{AOA}$ and comammox (Nitrospira spp.) are bacteria that are driving nitrifying process (Bartelme et al., 2017). This means that effect of AZA could have either a direct impact on nitrifying bacterial community, or, indirect, by optimizing environment for other types of bacteria, presumably heterotrophic, that could populate biofilter and thrive as better competitors in the new conditions (Blancheton et al. 2013). In any case, applying AZA to aquaponics is leading to higher concentrations of ammonia and nitrites which could eventually harm the fish or even lead to mortality. In the practical guideline for small- scale aquaponics, the recommendation is given for TAN concentration in the aquaponics to stay $<2 \mathrm{mg} \mathrm{L}^{-1}$ for Nile tilapia (Oreochromis niloticus), $<1 \mathrm{mg} \mathrm{L}^{-1}$ for majority of other fish species and $<0.5 \mathrm{mg} \mathrm{L}^{-1}$ for rainbow trout (Oncorhynchus mykiss) (Somerville et al., 2014). The toxicity of ammonia strongly depends on the $\mathrm{pH}$ levels and temperature of the water, as toxic, unionized fraction $\left(\mathrm{NH}_{3}-\mathrm{N}\right)$ prevails at high $\mathrm{pH}$ levels and at high water temperature (Randall \& Tsui, 2002). In the exposure tests, it was confirmed that concentration of 2 $\mathrm{mg} \mathrm{L}^{-1}$ did not cause mortality to the Nile tilapia, but some minor histopathological alterations in gills and liver were noted (Benli et al., 2008), while for the blue tilapia (Oreochromis aureus) there was no change in growth rate, feed conversion ratio and mortality in fish reared at $2.5 \mathrm{mg} \mathrm{L}^{-1}$ TAN during 53 days (Hargreaves \& Kucuk, 2001). As mentioned earlier, nitrites are less toxic compared to ammonia, and recommendations are that concentrations below $1 \mathrm{mg} \mathrm{L}^{-1}$ should be maintained in the aquaponics (Somerville et al., 2014). The $96 \mathrm{~h} \mathrm{LC} 50$ of nitrite-N for Nile tilapia is determined to be $81 \mathrm{mg} \mathrm{L}^{-1}$ for small fish and $8 \mathrm{mg} \mathrm{L}^{-1}$ for large fish (Atwood et al., 2001), although lethal concentrations are strongly depending on the chloride levels in the water (Yanbo et al., 2006). Effect of AZA on NOB/comammox in the present study led to fast and steady grow of nitrites- $\mathrm{N}$ concentrations in the water, reaching the value of $3 \mathrm{mg} \mathrm{L}^{-1}$ after only 53 hours in the study. This represents a considerable difference in AZA compared to other three groups and an increase from 91 to $143 \%$ after $45 \mathrm{~h}$ and from 57 to $75 \%$ after $53 \mathrm{~h}$. Mechanism of toxicity differ for two mentioned molecules, as ammonia is brain toxicant in fish (Randall \& Tsui, 2002), while nitrites are causing presence of methemoglobin and as a consequence reducing the concentrations of hemoglobin in the blood (Yildiz et al., 2006). On the other hand, nitrates are considered relatively safe for fish, and less toxic

Table 2. $96 \mathrm{~h} \mathrm{LC} 50$ values of azadirachtin, pyrethrum and chlorpyrifos for a number of fish species available in the literature.

\begin{tabular}{|c|c|c|}
\hline Fish species / active substance & $96 \mathrm{~h} \mathrm{LC}_{50}$ value & Reference \\
\hline \multicolumn{3}{|l|}{ Azadirachtin } \\
\hline Cyprinus carpio & $80.0 \mu \mathrm{L} \mathrm{L}^{-1}$ & (Murussi et al., 2016) \\
\hline Cyprinus carpio & $75.5 \mathrm{mg} \mathrm{L}^{-1}$ & (Davoodi \& Abdi, 2012) \\
\hline Heteropneustes fossilis & $52.3 \mathrm{mg} \mathrm{L}^{-1}$ & (Kumar et al., 2012) \\
\hline Labeo rohita & $42.7 \mathrm{mg} \mathrm{L}^{-1}$ & (Bhat et al., 2012) \\
\hline Oreochromis niloticus & $32.0 \mathrm{mg} \mathrm{L}^{-1}$ & (Oyoo-Okoth et al., 2011) \\
\hline \multicolumn{3}{|l|}{ Pyrethrum } \\
\hline Ictalurus punctatus & $114.0 \mu \mathrm{g} \mathrm{L}^{-1}$ & (Mauck et al., 1976) \\
\hline Lepomis raacrochirus & $49.0 \mu \mathrm{g} \mathrm{L}^{-1}$ & (Mauck et al., 1976) \\
\hline Oncorhynchus kisutch & $39.0 \mu \mathrm{g} \mathrm{L}^{-1}$ & (Mauck et al., 1976) \\
\hline Perca flavescens & $50.0 \mu \mathrm{g} \mathrm{L}^{-1}$ & (Mauck et al., 1976) \\
\hline Salmo gairdneri & $24.6 \mu \mathrm{g} \mathrm{L}^{-1}$ & (Mauck et al., 1976) \\
\hline \multicolumn{3}{|l|}{ Chlorpyrifos } \\
\hline Catla catla & $350.0 \mu \mathrm{g} \mathrm{L}^{-1}$ & (Tilak et al., 2004) \\
\hline Cirrhinus mrigala & $650.0 \mu \mathrm{g} \mathrm{L}^{-1}$ & (Tilak et al., 2004) \\
\hline Cyprinus carpio & $160.0 \mu \mathrm{g} \mathrm{L}^{-1}$ & (Halappa \& David, 2009) \\
\hline Labeo rohita & $470.0 \mu \mathrm{g} \mathrm{L}^{-1}$ & (Tilak et al., 2004) \\
\hline Oreochromis mossambicus & $26.0 \mu \mathrm{g} \mathrm{L}^{-1}$ & (Rao et al., 2003) \\
\hline Oreochromis niloticus & $1.0 \mathrm{mg} \mathrm{L}^{-1}$ & (Girón-Pérez et al., 2006) \\
\hline Salmo trutta caspius & $10.0 \mu \mathrm{g} \mathrm{L}^{-1}$ & (Adel et al., 2017) \\
\hline
\end{tabular}


comparing to ammonia and nitrites. 96h LC $\mathrm{C}_{50}$ concentrations for $\mathrm{NO}_{3}-\mathrm{N}$ are very high and ranging from 191 to $2400 \mathrm{mg} \mathrm{L}^{-1}$, depending on fish species (Camargo et al., 2005). Nitrates are easily taken by plants in the aquaponics, and the concentrations in the water would be lower if the present trial was done in full aquaponics setup (including plants). Plants can absorb ammonia from the water in the aquaponics, although to less extent comparing to nitrates, since $A O B$ and $\mathrm{NOB}$ are attached to the root surface of the plants (Hu et al., 2015). Even though the intention of the study was to use $\mathrm{CHL}$ as a positive control, as it is proven to have an effect on soil bacteria (Lo, 2010), the same was not noted in the present study, probably due to the different environment used (Stark \& Firestone, 1995), or due to the low concentration of pesticide in the water.

\section{Conclusions}

In conclusion, it was shown that applying AZA in the aquaponics setup is having a negative impact to concentrations of nitrogen compounds in both steps of nitrification. Therefore, caution has to be taken when this pesticide is applied. Other two pesticides did not show statistically significant difference from the control in any time point during the sampling. The major point of concern in aquaponics is lack of toxicological studies of three toxic molecules combined (ammonia, nitrites and pesticide), as fish can struggle in the presence of multiple toxicants in the environment. The obtained results should be used as a starting point in other research of effects of pesticides in aquaponics, since there is a lack of available literature published.

\section{Ethical Statement}

All listed co-authors declare that the present study was conducted in an ethical, professional and responsible manner.

\section{Funding Information}

This work was supported by the European Cooperation in Science and Technology (COST) under Grant FA1305 - "The EU Aquaponics Hub - Realising Sustainable Integrated Fish and Vegetable Production for the EU"; Ministry of Education, Youth and Sports of the Czech Republic under Grants "CENAKVA" (No. CZ.1.05/2.1.00/01.0024), "CENAKVA II" (No. LO1205 under the NPU I program) and by the NAZV project QJ1510119.

\section{Author Contributions}

Conceptualization - B.R. and J.M.; Formal Analysis - B.R. and J.M.; Investigation - B.R. and P.D.; Resources - P.D.; Writing-Original Draft Preparation - B.R.; WritingReview \& Editing - J.M. and P.D.; Visualization - B.R.; Project Administration - J.M.; Funding Acquisition - J.M.

\section{Conflict of Interest}

The authors declare that they have no known competing financial interests or personal relationships that could have appeared to influence the work reported in this paper.

\section{References}

Adel, M., Dadar, M., Khajavi, S.H., Pourgholam, R., Karimí, B., \& Velisek, J. (2017). Hematological, biochemical and histopathological changes in Caspian brown trout (Salmo trutta caspius Kessler, 1877) following exposure to sublethal concentrations of chlorpyrifos. Toxin Reviews, 36(1), 73-79.

https://doi.org/10.1080/15569543.2016.1230631

Ahmed, M.T., Ismail, S.M.M., \& Mabrouk, S.S. (1998). Residues of some chlorinated hydrocarbon pesticides in rain water, soil and ground water, and their influence on some soil microorganisms. Environment International, 24(5), 665-670. https://doi.org/10.1016/S01604120(98)00050-6

Atwood, H.L., Fontenot, Q.C., Tomasso, J.R., \& Isely, J.J. (2001). Toxicity of Nitrite to Nile Tilapia: Effect of Fish Size and Environmental Chloride. North American Journal of Aquaculture, 63(1), 49-51.

https://doi.org/10.1577/1548-

8454(2001)063<0049:TONTNT>2.0.CO;2

Bartelme, R.P., McLellan, S.L., \& Newton, R.J. (2017). Freshwater Recirculating Aquaculture System Operations Drive Biofilter Bacterial Community Shifts around a Stable Nitrifying Consortium of AmmoniaOxidizing Archaea and Comammox Nitrospira. Frontiers in Microbiology, 8, Article 101. https://doi.org/10.3389/fmicb.2017.00101

Benli, A.Ç.K., Köksal, G., \& Özkul, A. (2008). Sublethal ammonia exposure of Nile tilapia (Oreochromis niloticus L.): Effects on gill, liver and kidney histology. Chemosphere, 72(9), 1355-1358.

https://doi.org/10.1016/j.chemosphere.2008.04.037

Bhat, B.A., Bhat, I.A., Vishwakarma, S., Verma, A., \& Saxena, G. (2012). A Comparative Study on the Toxicity of a Synthetic Pesticide, Dichlorvos and a Neem based Pesticide, Neem-On to Labeo rohita (Hamilton). Current World Environment, 19(20), 157-161. https://doi.org/10.12944/cwe.7.1.24

Bittsánszky, A., Gyulai, G., Junge, R., Schmautz, Z., \& Komives, T. (2015, August 24-27). Plant protection in ecocyclebased agricultural systems: Aquaponics as an example [Poster presentation]. International Plant Protection Congress, Berlin, Germany.

Blanchard, J.L., Watson, R.A., Fulton, E.A., Cottrell, R.S., Nash, K.L., Bryndum-Buchholz, A., Büchner, M., Carozza, D.A., Cheung, W.W.L., Elliott, J., Davidson, L.N.K., Dulvy, N.K., Dunne, J.P., Eddy, T.D., Galbraith, E., Lotze, H.K., Maury, O., Müller, C., Tittensor, D.P., \& Jennings, S. (2017). Linked sustainability challenges and trade-offs among fisheries, aquaculture and agriculture. Nature Ecology \& Evolution, 1(9), 1240-1249. https://doi.org/10.1038/s41559-017-0258-8

Blancheton, J.P., Attramadal, K.J.K., Michaud, L., d'Orbcastel, E.R., \& Vadstein, O. (2013). Insight into bacterial population in aquaculture systems and its implication. Aquacultural Engineering, 53, 30-39. https://doi.org/10.1016/j.aquaeng.2012.11.009 
Bradbury, S.P., \& Coats, J.R. (1989). Toxicokinetics and toxicodynamics of pyrethroid insecticides in fish. Environmental Toxicology and Chemistry, 8(5), 373-380. https://doi.org/doi:10.1002/etc.5620080503

Camargo, J.A., Alonso, A., \& Salamanca, A. (2005). Nitrate toxicity to aquatic animals: a review with new data for freshwater invertebrates. Chemosphere, 58(9), 12551267.

https://doi.org/ 10.1016/j.chemosphere.2004.10.044

Davoodi, R., \& Abdi, G. (2012). Comparative Study on the Acute Toxicity of Synthetic Pesticides, Permethrin 25\% and Monocrotophos 36\%, and Neem-Based Pesticide, Neem Gold EC $0.03 \%$, to Juvenile Cyprinus carpio Linn. Journal of Biological \& Environmental Sciences, 6(16), 105-108.

Eddy, F.B., \& Williams, E.M. (1987). Nitrite and Freshwater Fish. Chemistry and Ecology, 3(1), 1-38. https://doi.org/10.1080/02757548708070832

Effendi, H., Wahyuningsih, S., \& Wardiatno, Y. (2017). The use of nile tilapia (Oreochromis niloticus) cultivation wastewater for the production of romaine lettuce (Lactuca sativa L. var. longifolia) in water recirculation system [journal article]. Applied Water Science, 7(6), 3055-3063. https://doi.org/10.1007/s13201-016-0418-z

Girón-Pérez, M.I., Barcelós-García, R., Vidal-Chavez, Z.G., Romero-Bañuelos, C.A., \& Robledo-Marenco, M.L. (2006). Effect of Chlorpyrifos on the Hematology and Phagocytic Activity of Nile Tilapia Cells (Oreochromis niloticus). Toxicology Mechanisms and Methods, 16(9), 495-499. https://doi.org/10.1080/15376510600751988

Goddek, S., Delaide, B., Mankasingh, U., Ragnarsdottir, K., Jijakli, H., \& Thorarinsdottir, R. (2015). Challenges of Sustainable and Commercial Aquaponics. Sustainability, 7(4), Article 4199. https://doi.org/10.3390/su7044199

Halappa, R., \& David, M. (2009). Behavioural Responses of the Freshwater Fish, Cyprinus carpio (Linnaeus) Following Sublethal Exposure to Chlorpyrifos. Turkish Journal of Fisheries and Aquatic Sciences, 9(2), 233-238. https://doi.org/10.4194/trjfas.2009.0218

Hargreaves, J.A., \& Kucuk, S. (2001). Effects of diel un-ionized ammonia fluctuation on juvenile hybrid striped bass, channel catfish, and blue tilapia. Aquaculture, 195(1), 163-181.

https://doi.org/10.1016/S0044-8486(00)00543-3

Hatzilazarou, S.P., Charizopoulos, E.T., PapadopoulouMourkidou, E., \& Economou, A.S. (2004). Dissipation of three organochlorine and four pyrethroid pesticides sprayed in a greenhouse environment during hydroponic cultivation of gerbera. Pest Management Science, 60(12), 1197-1204. https://doi.org/10.1002/ps.940

Hu, Z., Lee, J.W., Chandran, K., Kim, S., Brotto, A.C., \& Khanal, S.K. (2015). Effect of plant species on nitrogen recovery in aquaponics. Bioresource Technology, 188, 92-98. https://doi.org/ 10.1016/j.biortech.2015.01.013

Isman, M.B. (2020). Botanical Insecticides in the Twenty-First Century-Fulfilling Their Promise? Annual Review of Entomology, 65(1), 233-249.

https://doi.org/10.1146/annurev-ento-011019-025010

Junge, R., König, B., Villarroel, M., Komives, T., \& Jijakli, M. (2017). Strategic Points in Aquaponics. Water, 9(3), Article 182. https://doi.org/10.3390/w9030182

König, B., Junge, R., Bittsanszky, A., Villarroel, M., \& Komives, T. (2016). On the sustainability of aquaponics. Ecocycles, 2(1), 26-32. https://doi.org/10.19040/ecocycles.v2i1.50 Krüner, G., \& Rosenthal, H. (1983). Efficiency of nitrification in trickling filters using different substrates. Aquacultural Engineering, 2(1), 49-67. https://doi.org/ 10.1016/01448609(83)90005-5

Kumar, A., Prasad, M., Mishra, D., Srivastav, S.K., \& Kumar, A. (2012). Acute toxicity of azadirachtin to a teleost, Heteropneustes fossilis. Acta Scientiarum, 34(2), 213216. https://doi.org/10.4025/actascibiolsci.v34i2.9455

Lo, C.-C. (2010). Effect of pesticides on soil microbial community. Journal of Environmental Science and Health, Part B, 45(5), 348-359. https://doi.org/10.1080/03601231003799804

Love, D.C., Fry, J.P., Li, X., Hill, E.S., Genello, L., Semmens, K., \& Thompson, R.E. (2015). Commercial aquaponics production and profitability: Findings from an international survey. Aquaculture, 435, 67-74. https://doi.org/ 10.1016/j.aquaculture.2014.09.023

Macek, K.J., \& McAllister, W.A. (1970). Insecticide Susceptibility of Some Common Fish Family Representatives. Transactions of the American Fisheries Society, 99(1), 20-27. https://doi.org/10.1577/15488659(1970)99<20:ISOSCF>2.0.CO;2

Mauck, W.L., Olson, L.E., \& Marking, L.L. (1976). Toxicity of natural pyrethrins and five pyrethroids to fish. Archives of Environmental Contamination and Toxicology, 4(1), 18-29. https://doi.org/10.1007/bf02221012

Murussi, C.R., Menezes, C.C., Nunes, M.E.M., Araújo, M.d.C.S., Quadros, V.A., Rosemberg, D.B., \& Loro, V.L. (2016). Azadirachtin, a neem-derived biopesticide, impairs behavioral and hematological parameters in carp (Cyprinus carpio). Environmental Toxicology, 31(11), 1381-1388. https://doi.org/doi:10.1002/tox.22143

Oyoo-Okoth, E., Ngugi, C.C., \& Chepkirui-Boit, V. (2011). Physiological and Biochemical Responses of Nile Tilapia (Oreochromis niloticus) Exposed to Aqueous Extracts of Neem (Azadirachta indica). Journal of Applied Aquaculture, 23(2), 177-186.

https://doi.org/10.1080/10454438.2011.581588

Randall, D.J., \& Tsui, T.K.N. (2002). Ammonia toxicity in fish. Marine Pollution Bulletin, 45(1-12), 17-23. https://doi.org/10.1016/s0025-326x(02)00227-8

Rao, J.V., Rani, C.H.S., Kavitha, P., Rao, R.N., \& Madhavendra, S.S. (2003). Toxicity of Chlorpyrifos to the Fish Oreochromis mossambicus. Bulletin of Environmental Contamination and Toxicology, 70(5), 985-992. https://doi.org/10.1007/s00128-003-0079-0

Sirakov, I., Lutz, M., Graber, A., Mathis, A., Staykov, Y., Smits, T., \& Junge, R. (2016). Potential for Combined Biocontrol Activity against Fungal Fish and Plant Pathogens by Bacterial Isolates from a Model Aquaponic System. Water, 8(11), Article 518. https://doi.org/10.3390/w8110518

Somerville, C., Cohen, M., Pantanella, E., Stankus, A., \& Lovatelli, A. (2014). Small-scale aquaponic food production: integrated fish and plant farming. Food and Agriculture Organization of the United Nations, Rome, Italy.

Stark, J.M., \& Firestone, M.K. (1995). Mechanisms for soil moisture effects on activity of nitrifying bacteria. Applied and Environmental Microbiology, 61(1), 218-221. http://aem.asm.org/content/61/1/218.abstract

Svobodová, Z., Lloyd, R., Máchová, J., \& Vykusová, B. (1993). Water quality and fish health. Food and Agriculture Organization of the United Nations, Rome, Italy.

Tilak, K.S., Veeraiah, K., \& Rao, D.K. (2004). Toxicity and 
Bioaccumulation of Chlorpyrifos in Indian Carp Catla catla (Hamilton), Labeo rohita (Hamilton), and Cirrhinus mrigala (Hamilton) [journal article]. Bulletin of Environmental Contamination and Toxicology, 73(5), 933-941. https://doi.org/10.1007/s00128-004-0516-8

Troell, M., Naylor, R.L., Metian, M., Beveridge, M., Tyedmers, P.H., Folke, C., Arrow, K.J., Barrett, S., Crépin, A.-S. Ehrlich, P.R., Gren, Å., Kautsky, N., Levin, S.A., Nyborg, K., Österblom, H., Polasky, S., Scheffer, M., Walker, B.H., Xepapadeas, T., \& de Zeeuw, A. (2014). Does aquaculture add resilience to the global food system? Proceedings of the National Academy of Sciences, 111(37),13257-13263. https://doi.org/10.1073/pnas.1404067111

Turcios, A., \& Papenbrock, J. (2014). Sustainable Treatment of Aquaculture Effluents-What Can We Learn from the Past for the Future? Sustainability, 6(2), Article 836. https://doi.org/10.3390/su6020836

Ujváry, I. (2010). Chapter 3 - Pest Control Agents from Natural Products. In R. Krieger (Ed.), Hayes' Handbook of Pesticide Toxicology (Third Edition) (pp. 119-229). Academic Press. https://doi.org/ 10.1016/B978-0-12374367-1.00003-3

van Kessel, M.A.H.J., Speth, D.R., Albertsen, M., Nielsen, P.H., Op den Camp, H.J.M., Kartal, B., Jetten, M.S.M., \&
Lücker, S. (2015). Complete nitrification by a single microorganism. Nature, 528(7583), 555-559. https://doi.org/10.1038/nature16459

Villarroel, M., Junge, R., Komives, T., König, B., Plaza, I., Bittsánszky, A., \& Joly, A. (2016). Survey of Aquaponics in Europe. Water, 8(10), Article 468. https://doi.org/10.3390/w8100468

Wuertz, S., Schulze, S.G.E., Eberhardt, U., Schulz, C., \& Schroeder, J.P. (2013). Acute and chronic nitrite toxicity in juvenile pike-perch (Sander lucioperca) and its compensation by chloride. Comparative Biochemistry and Physiology Part C: Toxicology \& Pharmacology, 157(4), 352-360. https://doi.org/10.1016/j.cbpc.2013.01.002

Yanbo, W., Wenju, Z., Weifen, L., \& Zirong, X. (2006). Acute toxicity of nitrite on tilapia (Oreochromis niloticus) at different external chloride concentrations. Fish Physiology and Biochemistry, 32(1), 49. https://doi.org/10.1007/s10695-005-5744-2

Yildiz, H.Y., Köksal, G., Borazan, G., \& Benli, Ç.K. (2006). Nitriteinduced methemoglobinemia in Nile tilapia, Oreochromis niloticus. Journal of Applied Ichthyology, 22(5), 427-426. https://doi.org/ 10.1111/j.1439$0426.2006 .00761 . x$ 